\title{
Tensions linger over discovery of coronavirus
}

\section{A continuing row pits researchers against authorities in Saudi Arabia, where deadly pathogen was first isolated.}

\section{Declan Butler}

14 January 2013 | Corrected: 15 January 2013

When microbiologist Ali Mohamed Zaki mailed out a sample of a deadly virus he had found in Saudi Arabia to a leading virologist, he thought he was helping to alert the world to a potential public-health threat. But Saudi authorities are unhappy that, although the virus was first isolated in their country, Zaki's action has resulted in handing sovereign and intellectual-property rights on the first diagnostic tests or treatments over to an institute in the Netherlands.

As the World Health Organization convenes researchers and public health officials to a meeting in Cairo today to take stock of the novel virus, which has quickly sparked international concern, the dispute over its discovery continues. The row is highlighting potential tensions between scientists' pursuit of research and the responsibility they have to flag up threats to national authorities. It also underscores the lack of clear international rules for what rights and credit should be assigned to countries where pathogens are first isolated.

In June 2012, Zaki, who was then at the Dr Soliman Fakeeh Hospital in Jedda but has since returned to work in his native Egypt, isolated and cultured a virus from a man who had died of severe pneumonia and acute renal failure.

After routine diagnostics failed to identify the cause of death, Zaki contacted Ron Fouchier, a leading virologist at the Erasmus Medical Center (EMC) in Rotterdam,

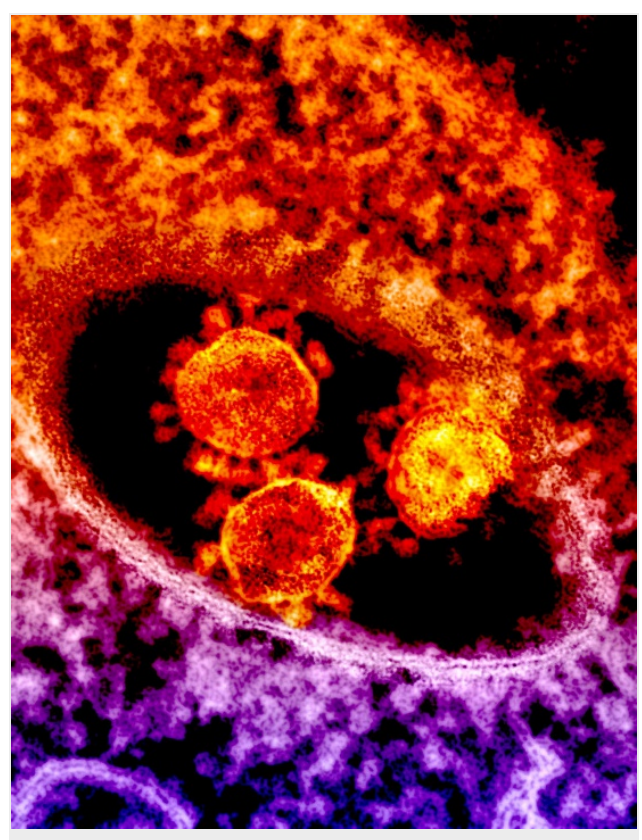

Elizabeth R. Fischer, Rocky Mountain Labs/N/AID/NIH A coronavirus discovered last year in Saudi Arabia is at the centre of an international controversy. the Netherlands, for advice. Fouchier, who last year made headlines for his work on H5N1 avian influenza, suggested that Zaki test for a coronavirus. The test came up positive.

\section{Crossing borders}

The virus subsequently caused small but deadly outbreaks in at least three countries in the Middle East and sparked international concern. The World Health Organization (WHO) reported on 21 December that its investigation of a cluster of cases in Jordan had raised suspicion that transmission could be occurring from human to human.

Meanwhile, Zaki had mailed a sample of the virus to Fouchier, who sequenced it and found that it was a previously unknown human coronavirus, closely related to one from bats. On 20 September, Zaki announced the discovery on ProMED-mail, an online diseasereporting system. The virus has since been provisionally named human betacoronavirus 2c EMC (hCoV-EMC), after the Rotterdam centre, and researchers wishing to acquire samples of its virus are now required to first sign an EMC material-transfer agreement (MTA).

Fouchier says that he has not denied any requests from scientists to obtain the virus, and that the MTA — and related patent applications - does not give Erasmus MC any ownership of the virus itself. Rather, it exerts rights that are based on work involving the viral sequence it generated — such as diagnostic tests, vaccines and antiviral treatments. In global health, claiming IP protection early is often also a defensive strategy, he adds, and claims are often dropped or never exercised at all.

Erasmus MC also wanted to restrict commercial exploitation by others of its work related to the virus, Fouchier says. Were scientists in Saudi Arabia to request samples of the virus, they would need to sign the MTA, he adds.

Saudi authorities are not happy, however. They claim that Zaki kept them in the dark about his work, including his shipment of the virus to the Netherlands. Ziad Memish, Saudi Arabia's deputy minister of health, asserts that national procedures for reporting potential new pathogens "were either intentionally or inadvertently circumvented". He also emphasises that under the WHO's 2005 International 
Health Regulations, all member states must report to the organisation any unusual and unidentified cases of severe disease that could be of international concern.

Zaki claims that he complied with procedures by submitting a virus sample and associated clinical data to the Saudi health ministry on 18 June, and that the ministry did not sufficiently follow up. Memish, however, says that the sample was sent without a sufficient red flag. Zaki adds, however, that he only informed authorities of subsequent progress on the same day as his ProMED post. "My responsibility stops at sending the sample and giving them the clinical data, and they are the ones that then have to decide what to do," he says.

\section{Missing framework}

Zaki adds that he wanted to first be "very sure" of having correctly identified the virus before reporting its discovery. Without his personal initiative, he says, the world might not have been alerted to the potential new threat as soon as it was. Had Saudi authorities been informed in advance, he contends, they might have been reluctant to make the findings public until after the annual hajj religious rituals in late October, which are attended by millions of people from all over the world.

Memish dismisses this concern as unfounded, noting that the government called in external investigators - from the WHO and the US Centers for Disease Control and Prevention, among others - as soon as it learned of the discovery.

"We were very transparent, we did not hide anything," Memish says, arguing that had they been informed, "at least we would have been involved in the investigation, have had access to the virus and been able to work with others".

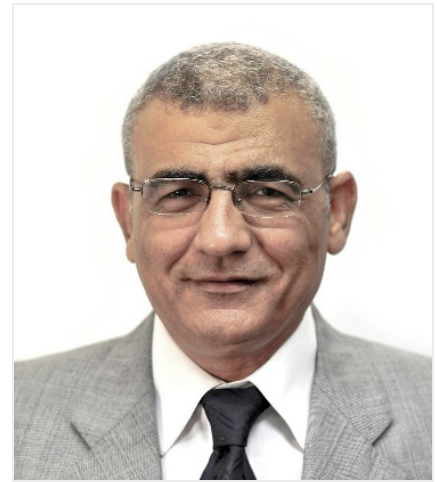

Ali Mohamed Zaki first isolated the coronavirus at the center of the controversy.

Some researchers sympathise with Zaki's position, arguing that Zaki was just seeking help to elucidate the cause of the patient's death, and could not have known that he would discover a virus that would soon spread to several countries.

But David Heymann, chairman of the UK Health Protection Agency, says that any government would be embarrassed were its researchers to go public without informing it beforehand. At the same time, he says, it is also good that the international scientific community learned about the virus - which, for example, enabled it to quickly develop diagnostics.

What has also riled Saudi authorities, and some researchers, is the fact that the EMC has control over researchers' access to samples of its virus culture, even though the virus was first isolated and cultured in Saudi Arabia. Who owns what rights on virus samples can be a politically charged issue in global health. The Convention on Biological Diversity (CBD) provides countries with sovereign rights to their biological resources, but how this applies to viral samples of potential global-health significance is unclear.

Indonesia has set a partial precedent. In 2005, the country invoked the CBD as partial grounds for refusing to provide the WHO with samples of $\mathrm{H} 5 \mathrm{~N} 1$ avian flu viruses from outbreaks there, arguing that it would see few returns — such as IP and technology-transfer rights, scientific collaborations or access to H5N1 drugs and vaccines. After six years of negotiation, the WHO last year reached an international agreement on a 'pandemic influenza preparedness framework' that accepts this logic and provides some benefits for countries supplying viruses isolated in their territory. But international rules for sharing have not been developed for any other virus.

lan Lipkin, a virologist at Columbia University in New York, who in October investigated the coronavirus cases in Saudi Arabia on the invitation of authorities there, says that researchers working in global public health need to be sensitive to issues such as sovereignty and national pride, and IP rights on samples. "There is some irritation that this virus, which was actually isolated [in Saudi Arabia], is the intellectual property of a European institution," Lipkin says. "I can understand why they would be upset."

Fouchier argues, however, that MTAs on viruses are standard practice - they help to clarify terms and conditions of sample use and deal with issues related to liability and security, he says.

Ultimately, there is a need for a global agreement about ownership and sharing of virus samples, says Memish. The WHO declined to comment for this article. Meanwhile, the agency has convened researchers and public health officials to a meeting in Cairo today and tomorrow to take stock of what's known about the novel coronavirus. "The potential of the virus to cause widespread serious consequences is thought to be significant, yet current knowledge of its epidemiology and natural history of infection with this agent is limited," it said in a statement. 
Nature | doi:10.1038/nature.2012.12108

\section{Corrections}

Corrected:The original version of this article stated that the WHO's Technical consultative meeting on novel human coronavirus is taking place in Geneva. The correct location is Cairo. 